\title{
REVIEW OF CURRENT RESEARCH
}

\section{The Case for an "Abnormal" Insulin in Diabetes Mellitus"}

\author{
Claude C. Roy, Dennis J. Shapcott, and Donough O'Brien \\ Department of Pediatrics, University of Colorado Medical Center
}

Received: December 21, 1967

\begin{abstract}
Summary. Understanding of diabetes in molecular terms has advanced very little. The possibility that a structural difference exists in the circulating and pancreatic insulin moiety of diabetics is supported by three lines of evidence obtained in the author's laboratory. Immunologically purified circulating insulin from diabetic subjects untreated with insulin was noted to be relatively resistant to degradation by a crude muscle insulinase preparation. The pancreatic insulin of five diabetic pancreases was found to have a decreased biological activity in its ability to enhance glycogen synthesis in vivo and in its capacity to stimulate RNA turnover in tissue culture. - The nature of this "abnormal insulin" and its hypothetical role in the physiopathology of diabetes are discussed in the light of the need for a specific definition of the precise molecular change.
\end{abstract}

Exposé des arguments en faveur d'une, ,insuline anormale" dans le diabète

Résumé. Peu de progrès conduisant à la compréhension du diabète en termes moléculaires ont été réalisés. La possibilité qu'il existe une modification dans la structure de l'insuline des diabétiques, aussi bien circulante que pancréatique, s'appuie sur trois arguments expérimentaux obtenus au laboratoire des auteurs. - La purification immunochimique de l'insuline circulante de diabétiques jeunes non traités par l'insuline a d'abord conduit à la constatation que cette insuline est relativement résistante à l'action réductrice et protéolytique d'une préparation d'insulinase musculaire. De plus, l'insuline pancréatique, isolée à partir de einq pancréas diabétiques, s'est avérée d'activité biologique diminuée quant à son pouvoir d'augmenter la synthèse du glycogène in vivo et à sa capacité d'accélérer le "turnover" du
R.N.A. en culture tissulaire. - La, nature de cette ,insuline anormale" et son rôle possible dans la physiopathologie du diabète sont examinés à la lumière de la nécessité de donner une définition spécifique de la modification moléculaire précise.

Befunde, die für das Vorliegen eines „abnormen" Insulins bei Diabetes mellitus sprechen

Zusammenfassung. Unsere Kenntnisse über den Diabetes in molekularbiologischer Sicht haben kaum Fortschritte gemacht. Die Möglichkeit, daß das zirkulierende und das Pankreas-Insulin des Diabetikers strukturelle Unterschiede aufweisen, wird durch die Ergebnisse von drei verschiedenen Untersuchungsreihen gestïtzt, die im Laboratorium der Verfasser durchgeführt wurden. Immunologisch gereinigtes zirkulierendes Insulin von Diabetikern, die noch kein Insulin erhalten hatten, erwies sich als recht widerstandsfähig gegenüber dem Abbau durch ein Insulinase-Rohextrakt aus Muskelgewebe. Aus den Bauchspeicheldrüsen von 5 Diabetikern gewonnenes Insulin zeigte sowohl in seiner Fähigkeit, die GlycogenSynthese in vivo, als auch den Ribonucleinsäuren-Umsatz in der Gewebskultur zu stimulieren, eine herabgesetzte biologische Aktivität. - Bei der Diskussion der Natur dieses ,abnormen" Insulins und seiner hypothetischen Rolle in der Physiopathologie des Diabetes ergibt sich besonders deutlich, wie dringend erforderlich eine genauere Klärung des in diesem Falle vorliegenden molekularen Umbaus ist.

Key-words : Insulin, diabetes, insulinase, rat diaphragm, glycogen synthesis, RNA turnover, cell culture, anti-insulin serum.
Despite extensive research on the physiopathology of diabetes, understanding of this disease in molecular terms has advanced very little. The advent of bioassays and more recently of immunoassays which now occupy a central position in hormone research have clearly shown that insulin deficiency offers no total explanation for diabetes.

The possibility that a structural difference exists in the circulating and pancreatic insulin moiety of diabetic subjects is an attractive and logical hypothesis which has begun to invite the attention of a few investigators $[30,41,12,37]$. The present review examines the evidence obtained in our laboratory.

* This work was supported by U.S. Public Health Service Grants nos. HD-2578-01 and FR-69.

\section{Evidence for an abnormal insulin}

The first tentative evidence favouring this idea resulted from a study in vitro utilizing rat hemidiaphragms incubated with a known excess of bovine insulin to which was added either normal serum or the serum of adult onset diabetics or of juvenile diabetics [44]. The rate of disappearance of insulin was significantly slower in the samples incubated with diabetic serum. At that time, the most acceptable explanation seemed to be that serum from diabetics contained an inhibitor preventing the attachment of insulin to its receptor site on the diaphragm muscle (Fig. 1).

Since the experiment could be repeated using a particle-free supernatant of rat diaphragm, this effect clearly appeared independent of an intact muscle membrane. Thus, the notion that the differences ob- 
served were possibly related to a serum inhibitor such as $B$ chains [9] competing for active sites on the cell membrane became unlikely and was finally discounted when reduced $\mathbf{B}$ chains failed to modify the results.

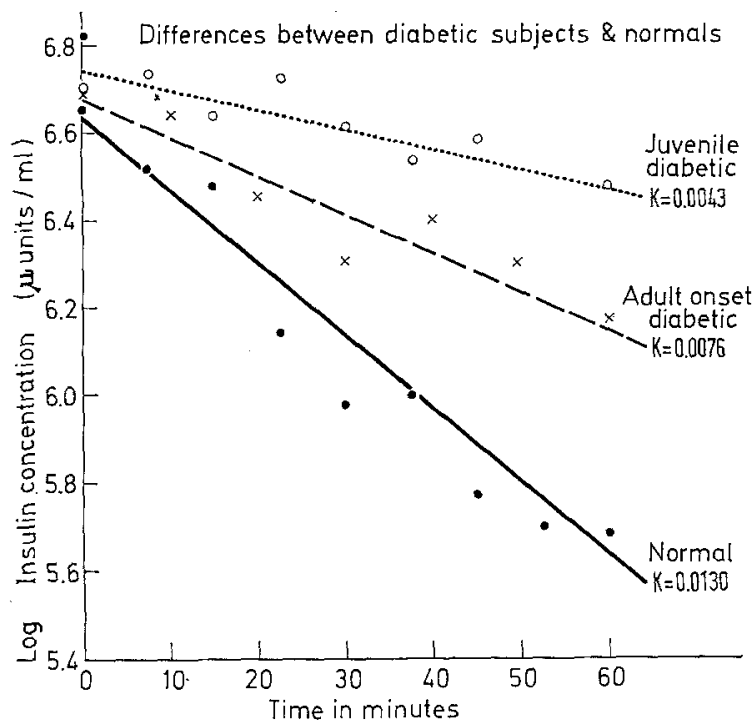

Fig. 1. Differences between diabetic subjects and normals
A. Resistance to "insulinase" of serum derived diabetic insulin

The logical exploitation of these initial observations led, therefore, to an experiment involving the incubation with a crude muscle insulinase preparation of insulin extracted from the serum of normal and of juvenile diabetic subjects who, at the time of sampling, had never been injected with insulin.

Since conventional purification methods could not be used for the small amounts of insulin recoverable from serum, an immunological purification technique was devised. As shown in Fig. 2, it involved basically three gel filtrations in conjunction with the combination and release of the peptide serum fraction from anti-insulin serum. A fixed volume of the final fraction containing between 50 and $430 \mu \mathrm{U} / \mathrm{ml}$ of insulin was incubated at $38^{\circ} \mathrm{C}$ for two consecutive periods of $30 \mathrm{~min}$ with a crude rat muscle insulinase preparation. Triplicate samples were withdrawn at 0.30 , and $60 \mathrm{~min}$ and blown into ice cold buffer for subsequent immunoassay by a double antibody technique modified from Morgan and Lazarow [28]. An initial study showed that insulin isolated from the serum of seven untreated. juvenile diabetios was significantly more resistant to

1 vol. serum +1 vol. $1 \mathrm{~N}$ acetic acid stand at room temp. for $60 \mathrm{~min}$.

Gel filter on $60 \times 4 \mathrm{~cm}$. Sephadex G 50

$50-80 \mathrm{ml} / \mathrm{h} 0.5 \mathrm{~N}$ acetic as eluent.

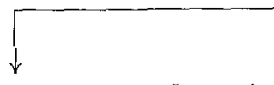

Discard protein and second optically dense peak. (Soe Fig. 2)
Retain peptide fraction. Combine with guinea pig anti-insulin. Gel filter as above using 0.1 M Borate buffer $(\mathrm{pH} \mathrm{8.2)}$ as eluent.

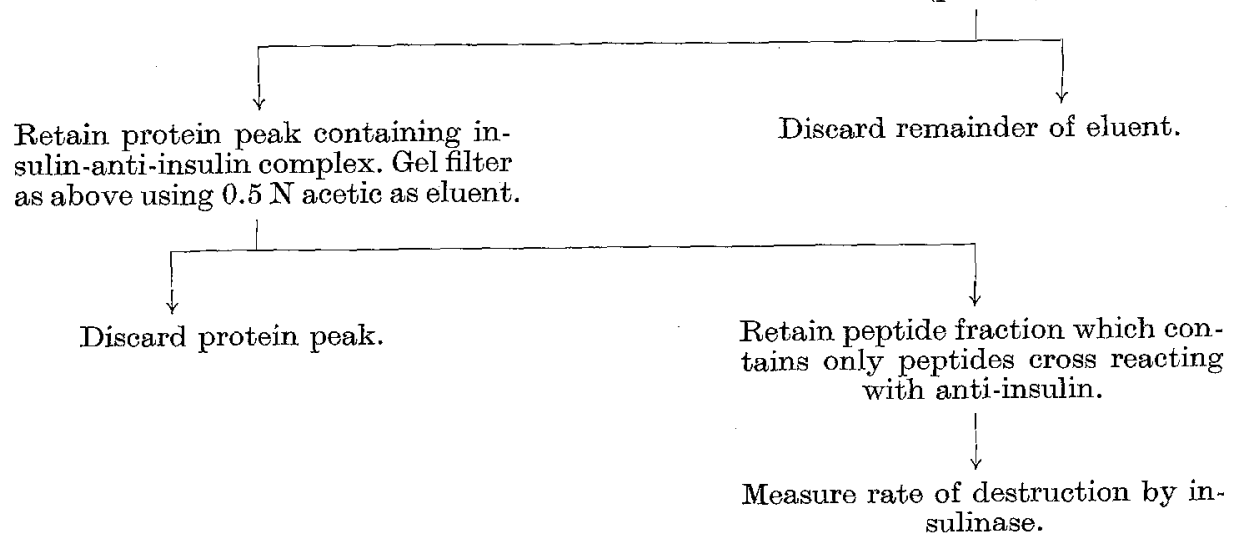

Fig. 2. Outline for technic for isolating insulin from serum

Reproduced with kind permission of R.B. ELLIOTT, D. O'BRIEN, and C.C. Roy:
Although this experiment did not exclude the possibility of a serum factor effecting the complexing of insulin [1], it did seem possible that the "inhibitor" in diabetic serum was actually an "abnormal" insulin. destruction by a crude rat insulinase preparation than normal insulin derived from either serum or pancreas [8]. Subsequently, these results were confirmed when serum derived insulin from 15 untreated juvenile dia- 
betics, 16 parents of juvenile diabetics and 17 healthy adults were studied (Fig. 3). The fact that the parents of juvenile diabetics exhibited a degree of insulin resistance which was statistically different from the resistance observed in the normal controls and in the juvenile diabetics suggested that possibly these three populations could represent three genotypes with respect to a simple mendelian pattern of inheritance [35].

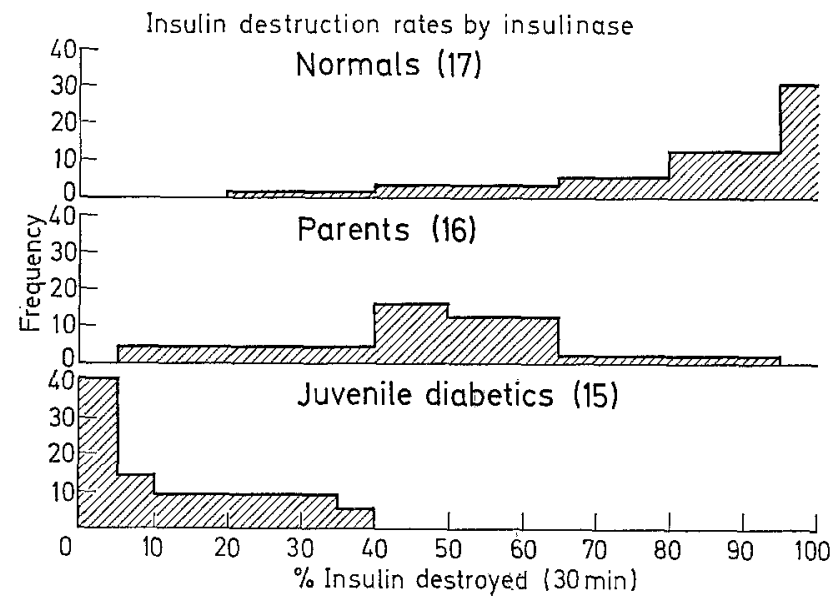

Fig. 3. Insulin destruction rates by insulinase Reproduced with kind permission of C.C. RoY, R.B. Elitott, D.J. Shapcott, and D. O'Brien: Lancet 1966 II, $1433-1435$

The particular importance of these studies is that they demonstrate an apparently heritable difference between normal and diabetic insulin, thereby implying some structural alteration in the latter. It is immaterial, at this juncture, whether the critical step was at some stage in proteolysis or in the somewhat independent and initial process [17] of splitting the disulphide bonds by "glutathione-insulin transhydrogenase" [15].

\section{insulin.}

B. Impaired biological activity of pancreatic diabetic

The prolonged half-life of both labelled [4] and unlabelled [34] insulin injected intravenously in diabetic subjects could possibly relate to some defect in diabetic "insulinase". In fact, this has not been shown to be the case [26], and furthermore, it would hardly fit with our observation that diabetic insulin itself is resistant to this enzymatic system. Much more probable is the existence of an altered molecular geometry of the insulin giving rise to a decreased turnover rate.

In theory, such an arrangement might be of benefit to diabetics since their circulating insulin has a longer biological half life. On the other hand, this longer half life might not represent a true biological advantage and could represent a decreased physiological action through an impaired "hormone receptor interaction" [37].
1. Glycogen synthesis. Metabolic parameters other than glucose transport and oxidation are perhaps affected in a more primary and specific manner by insulin. Exploitation of the observation that insulin mediated glucose transport fav ours the glycogen storage pathway [47] led to a recently described intraperitoneal assay [32] which was used to compare the biological activity of identical immunoassayable amounts of normal and diabetic pancreatic insulin.

Insulin was prepared from five human diabetics and from one normal pancreas by acid ethanol extraction [27]. The insulin content of pancreatic extracts was assayed by a double antibody technique [28]. For each experiment, aliquots of the control and diabetic pancreatic insulins were assayed three times in triplicate. A mixture of insulin and ${ }^{14} \mathrm{C}$-glucose was then injected intraperitoneally into Wistar rats, controls were injected with ${ }^{14} \mathrm{C}$ glucose alone. Two hours after injection, the animals were killed, the diaphragms removed and weighed. The incorporation of glucose into glycogen was estimated directly by measuring the activity of the total ethanol-precipitable glycogen per $\mathrm{mg}$ of wet weight of diaphragm.

The results of this first part of the study in Fig. 4 show that the increase in glycogen synthesis with diabetic insulin was significantly less in all cases than with non-diabetic insulin [29]. These differences could not be accounted for by the presence in the pancreatic extracts of significant amounts of either glucagon, catechols, or corticosteroids, and no effects of B chains added to normal pancreatic insulin could be observed.

\begin{tabular}{|c|c|c|c|c|}
\hline & \multirow[b]{2}{*}{$\begin{array}{l}\text { No. of } \\
\text { animals }\end{array}$} & \multicolumn{3}{|c|}{$\begin{array}{l}\text { Counts in ethanol } \\
\text { precipitable } \\
\text { glycogen/mg diaphragm }\end{array}$} \\
\hline & & $\bar{x}$ & S.D. & $P$ \\
\hline Controls & 14 & 1.2 & 1.1 & \\
\hline $\begin{array}{l}\text { Normal pancreas } \\
\text { Diabetic pancreas \# } 1\end{array}$ & $\begin{array}{l}8 \\
7\end{array}$ & $\begin{array}{l}58.4 \\
10.5\end{array}$ & $\begin{array}{r}25.1 \\
6.0\end{array}$ & $<0.01$ \\
\hline $\begin{array}{l}\text { Normal pancreas } \\
\text { Diabetic pancreas \# } 2\end{array}$ & $\begin{array}{r}9 \\
10\end{array}$ & $\begin{array}{l}31.6 \\
14.5\end{array}$ & $\begin{array}{r}12.1 \\
6.2\end{array}$ & $<0.01$ \\
\hline $\begin{array}{l}\text { Normal pancreas } \\
\text { Diabetic pancreas } \# \mathbf{3}\end{array}$ & $\begin{array}{l}8 \\
7\end{array}$ & $\begin{array}{r}12.0 \\
5.5\end{array}$ & $\begin{array}{l}4.7 \\
2.6\end{array}$ & $<0.01$ \\
\hline $\begin{array}{l}\text { Normal pancreas } \\
\text { Diabetic pancreas \# } 4\end{array}$ & $\begin{array}{r}10 \\
8\end{array}$ & $\begin{array}{r}26.6 \\
6.5\end{array}$ & $\begin{array}{r}10.7 \\
3.4\end{array}$ & $<0.01$ \\
\hline $\begin{array}{l}\text { Normal pancreas } \\
\text { Diabetic pancreas } \# 5\end{array}$ & $\begin{array}{r}10 \\
9\end{array}$ & $\begin{array}{l}21.9 \\
10.0\end{array}$ & $\begin{array}{l}8.8 \\
6.2\end{array}$ & $<0.01$ \\
\hline
\end{tabular}

Fig. 4. ${ }^{14} \mathrm{C}$-Glucose incorporation into diaphragmatic glycogen with acid ethanol extracted pancreatic insulins

Despite the evidence that the immunoassay procedure detects total pancreatic insulin regardless of its free or combined state [24], a recent paper [31] suggests that an immunologically inactive fraction of I.L.A. is produced by the pancreas. While chemically different from insulin, this pancreatic I.L.A. appears to have similar biological effects. Thus, it is possible that the differences in biological activity could be 
accounted for by the presence of more pancreatic I. L.A. in the acid ethanol extracts of normal pancreas than in the diabetic pancreatic samples. For this reason, one normal and one diabetic pancreas were first

\begin{tabular}{lllll}
\hline & & $\begin{array}{l}\text { Counts in ethanol } \\
\text { precipitable gly- } \\
\text { cogen/mg of diaphragm }\end{array}$ \\
\hline & \begin{tabular}{llll} 
No. of & $\bar{x}$ & S.D. & $P$ \\
\hline $\begin{array}{llll}\text { animals } \\
\text { Normal pancreas }\end{array}$ & 25 & 42.2 & 21.9
\end{tabular}$<.01$ \\
\hline Diabetic pancreas & 25 & 24.4 & 15.3 \\
\hline
\end{tabular}

Fig. 5. ${ }^{14} \mathrm{C}$-glucose incorporation into diaphragmatic glycogen with immunologically purified insulins

\footnotetext{
Acid ethanol extraction$$
\downarrow
$$$$
\text { Re-extraction after } 18 \mathrm{~h} \text { at } 4^{\circ} \mathrm{C}
$$$$
\downarrow
$$

Combined supernatants taken to ph 7.5 with conc. ammonia

Etorr $15 \mathrm{ml}$ and ether $25 \mathrm{ml}$ to each $9 \mathrm{ml}$ of supernatant $\downarrow$

Precipitate dissolved with $1 \mathrm{~m}$ acetic acid $\downarrow$

Gel filtration (Sephadex G 50) of the freeze-dried supernatant suspended in $1 \mathrm{~m}$ acetic acid

$\downarrow$

Gel filtration of the peptide fraction with polyacrylamide gel (Biorad $P_{4}$ )
$\downarrow$
Immunoassay

Fig. 6. Isolation of insulin from human pancreas
}

the primary impact is immunologic, biologic, or both is immaterial to the argument that there is a difference between normal and diabetic insulin.

2. $K N A$ turnover. As with all hormones, the assignment of a single specific mechanism of action for insulin has not been possible. However, insulin is known to enhance bond formation and carbon chain increase (protein, fat, carbohydrate, RNA) in all mammalian systems.

Thus, a third line of evidence favouring the presence of an abnormal insulin in diabetes was found when a significant difference in the incorporation of uracil${ }_{2}{ }^{14} \mathrm{C}$ in the RNA fraction of mouse fibroblast cultures incubated with identical immunoassayable amounts of acid ethanol extracted insulin from two normal and from five diabetic pancreases was observed. Further purification (Fig. 6) of pooled samples of normal and diabetic pancreatic insulin by means of gel filtration through Sephadex and subsequently of the peptide fraction through Polyacrylamide gel gave comparable results (Fig. 7).

A well-established mouse fibroblast cell line (strain $3 \mathrm{~T}_{6}$ ) was used. This tetraploid cell line has been well studied [45]; it has a doubling time of $13 \mathrm{~h}$ and is known to produce collagen [11]. All inoculations and transfers were in the form of trypsinized cell suspensions. The cells were inoculated while in log phase at a density of $5 \times 10^{5}$ in plastic petri dishes. The nutrient medium was changed during the log phase and replaced by fresh medium containing 5000 microunits of insulin and 0.5 microunit of uracil-2- ${ }^{14} \mathrm{C}$. The incubation period with insulin and uracil-2.14 $\mathrm{C}$ added medium was terminated by the addition of iced distilled water. Extraction of the nucleic acid protein complex was achieved by a modification of the Schmidt Tannhauser method [7]. The RNA was estimated by the orcinol reaction [25] and the specific activity of

\begin{tabular}{llclcc}
\hline \multirow{2}{*}{$\begin{array}{l}\text { Crude acid } \\
\text { ethanol extracts }\end{array}$} & \# Plates & $\begin{array}{l}\text { RNA S.A. } \\
(\text { mean) }\end{array}$ & S.D. & $P$ \\
\cline { 2 - 7 } & Diabetic (5) & 10 & 263 & 107 & $<.01$ \\
\hline Purified acid & Pooled normal & $\mathbf{9}$ & $\mathbf{3 5 0}$ & 40 & $<.01$ \\
\cline { 2 - 7 } ethanol extracts & Pooled diabetic & 8 & $\mathbf{5 6}$ & 12 & \\
\hline
\end{tabular}

Fig. 7. Comparison between normal and pancreatic diabetic insulin

extracted with $1 \mathrm{~m}$ acetic acid, and the insulin separated immunochemically using essentially the technique [8] described to isolate insulin from serum. The results in Fig. 5 using immunologically purified normal and diabetic pancreatic insulin confirmed the results obtained in the first part of the experiment.

An objection to the above results is that diabetic insulin might have an increased affinity for anti-insulin serum. As a result of this, a lower molar concentration of diabetic insulin would have been used in this, in vivo, assay of biological activity. Nevertheless, whether the RNA fraction was counted in a Packard Tricarb liquid scintillation counter.

Fig. 7 illustrates a significant difference between the RNA specific activity of mouse fibroblast cultures grown with normal and those grown with diabetic pancreatic insulin [36].

At present, the molecular site of action of insulin is unknown [22]. Since insulin activates spatially separated systems in the cell, it is plausible that the hormone provides multiple-intracellular signals [21] which are operative at the gene locus influencing the 
rate of transcription of genetic units or at the level of ribosomes [33] influencing translation and therefore the rate of $\mathrm{mRNA}$ utilization [48]. This unitarian view involving nucleic acid metabolism as a primary site of insulin action has allowed the separation between normal and diabetic pancreatic insulin in terms of its stimulative role on RNA turnover.

\section{Nature of the "abnormal insulin"}

The insulin molecule consists of two polypeptide chains interconnected by two disulfide bridges with a third intrachain disulfide bond within the A chain. An important contribution to the mode of insulin biosynthesis was made when evidence for the separate synthesis of the two polypeptide chains was obtained [13]. The question as to how the two chains are combined so that correct disulfide pairing is obtained remains unsettled. Glutathione-insulin transhydrogenase, responsible for the initial step in the degradation of insulin, by bringing about the reductive cleavage of its disulfide bonds [46] has now been demonstrated in the acinar tissue of pancreas [19]. The resynthesis of biologically active hormone from its inactive reduced chains has been shown; it appears, therefore, that the reaction of insulin with glutathione-insulin transhydrogenase is reversible [16]. The possible role of this particular enzyme in the final coupling of the $A$ and $B$ chains of insulin remains unknown [20]. From studies on the resynthesis of insulin from its reduced chains, the formation of insulin from the two chains can occur spontaneously and it is likely that information leading to correct disulfide pairing is contained in the amino acid sequence of the separate insulin chains [6].

The objections to the idea of inappropriate alignment and union of subunits secondary to either an abnormal insulin synthetase (glutathione-insulin transhydrogenase) or to an altered amino acid sequence of the $\mathbf{A}$ and $B$ chains is that insulin is not a unique molecule. Despite considerable variations in primary structure from species to species, these insulins, milligram for milligram, possess similar biological activities. Even though it is difficult to fit insulin into the concept that the biological activity of a hormone is entirely dependent upon its covalent structure, from degradative studies [5] and from the admirable work on the chemical synthesis of insulin [14], a certain core structure appears necessary to hold the molecule in a particular three dimensional pattern for full expression of biological activity.

The abnormal resistance of diabetic insulin to insulinase may very well be indicative of some structural change in the insulin molecule making the disulfide bonds less readily available to the action of the enzyme and more resistant to proteolysis. The further demonstration of decreased biological activity of pancreatic diabetic insulin in its capacity to stimulate glycogen synthesis and RNA turnover would constitute more arguments favouring a structural change.
Convincing as these studies are, they are not conclusive. One investigator, for example, has crystallized insulin from human diabetic and normal pancreas and found only very tentative evidence of any difference of hydrolysis products [18]. These results can be explained in a number of ways still consistent with the hypothesis of an abnormal insulin. In the first place, the hydrolysate analysis showed sufficient variance as to suggest that they might obscure a single amino acid change, particularly in those with the largest number of residues. Secondly, the procedure does not distinguish aspartic acid from asparagine, or glutamic acid from glutamine [38]. Finally, of course, a normal hydrolysate analysis is still consistent with a sequence change or even with a methodology that fails to extract the abnormal insulin.

Even if the biological differentiations found so far between normal and diabetic insulin cannot be confirmed in terms of sequence analysis, the possibility of a spatial conformation change cannot be rejected. Theoretically, insulins of identical amino acid sequence should react identically as far as antigenity is concerned; but widely varying reactivity to anti-insulin serum have been noted between sperm whale and pork insulin which have the same amino acid sequence. Against certain human anti-insulin serums, dog insulin is distinguishable from pork insulin, although both have an identical primary structure [2]. From these data, it is possible that the spatial conformation of a protein is perhaps not solely determined by amino acid sequence and that there may be genetic control over the conformation of proteins as well [40].

An abnormal polymerization of the insulin molecule in diabetes resulting from a steric change is certainly plausible. Disruptive changes in the secondary structure of the molecule affects the ability of the molecule to aggregate [39]. The recent evidence farouring the presence of an insulin precursor in isolated islets of Langerhans might be a very attractive explanation for the "abnormal insulin concept". This pro-insulin is a larger molecule [42]; it yields insulin on mild tryptic digestion, has immunological properties similar to insulin [41], and could possibly have reduced biological attributes. It seems unlikely, however, that this higher molecular weight substance would have separated out in the insulin fraction obtained from serum in the "insulinase" study [8] and from the pancreas in the glycogen synthesis experiment [35].

\section{Significance of abnormal insulin in terms of the physiopathology of the disease}

The idea of an "abnormal insulin", well founded as it now is, offers no all encompassing explanation of diabetes mellitus. It helps very little in the understanding of the wide range in age and severity of the disease. Because of the high frequency of the diabetic gene, it is not inconceivable that insulin is a poly- 
morphic protein, relative proportions of various forms of insulin being present in the same individual. Furthermore, the case for an "abnormal insulin" might well explain maturity-onset diabetes with high circulating levels of insulin and the relative absence of pancreatic changes over the years; it fails to account, however, for the early and progressive pathological changes in the pancreas of the juvenile [10] leading to the complete absence of endogenous insulin after two or three years of disease.

The possible role of an autoimmune reaction in the aetiology of diabetes is supported by the presence of eosinophilic infiltrates in the islets of infants of diabetic mothers [37], by the frequent early observation of "insulitis" in patients with juvenile, acute-onset diabetes [21] and by the presence of human insulin antibodies detected by immunofluorescence techniques [23]. If an autoimmune component were involved in the physiopathology of diabetes, the reaction could be directed against insulin-producing cells [34], and possibly triggered by the production of an "abnormal insulin" perceived by immune-competent cells as a foreign protein.

The definitive answer to the implications of an "abnormal insulin" must await both a specific definition of the precise molecular change and a much more profound understanding of the cellular metabolic implications of such a difference.

Acknowledgment. We gratefully acknowledge the valuable technical assistance of Miss Clara Trombley and the editorial assistance of Mrs. Nina Pautr.

\section{References}

1. Antoniades, H.N., J.A. Bougas, H.M. Pyle, R. Camerint-Davalos, and K. Gunderser: Studies on the state of insulin in blood. The regulation of "free" insulin and insulin complexes in the blood of diabetic and non-diabetic subjects. Now Engl. J. Med. 267, $953-957$ (1962).

2. Berson, S.A., and R.S. YArow: Insulin in blood and insulin antibodies. Amer. J. Med. 40, 676 - 690 (1966).

3. - - Some current controversies in diabetes research. Diabetes 14, 549-572 (1965).

4. Bolinger, R. E., J.H. MorRTs, F. G. MoKNIGHT, and D.A. DrenenioH: Disappearance of I-131-labelled insulin from plasma as a guide to management of diabetes. New Engl. J. Med. 270, 767-770 (1964).

5. CARPENTER, F.H. : Relationship of structure to biological activity of insulin as revealed by degradative studies. Amer. J. Med. 40, 750-758 (1966).

6. DU, Y.-C., R.-Q. JIANG, and C.-L. Tsou: Conditions for successful resynthesis of insulin from its glycyl and phenylalanine chains. Sc. Sinica 14, 229-236 (1965).

7. EIDAM, C.R., and D.J. Mwromant : The plateau phase of growth of the L-M strain mouse cell in a proteinfree medium. I. Patterns of protein and nucleic acid synthesis and turnover. Exp. Cell Res. 27, 132-139 (1965).

8. ELLIOTT, R.B., D. O'Brien, and C.C. Roy: An abnormal insulin in juvenile diabetes mollitus. Diabetes 14, $780-787(1965)$.

9. ENSINOK, J., and J. VALIANCE-OWEN: Antagonism of insulin by the albumin-bound " $B$ " chain of insulin. Diabetes 12, 353-354 (1963).
10. Gapts, W.: Pathological anatomy of the pancreas in juvenile diabetes mellitus. Diabetes 14, 619-633 (1965).

11. Goldberg, B., H. Green, and G.J. Todaro: Collagen formation in vitro by established mammalian cell lines. Exp. Cell Res. 31, 444-447 (1963).

12. Huff, T.A., E.S. Horton, and H.E. Lebovitz: Abnormal insulin secretion in myotonic dystrophy. New Engl. J. Med. 277, 837-841 (1967).

13. HUMBEL, R.S.: Biosynthesis of the two chains of insulin. Proc. nat. Acad. Sci. (USA) 53, 853-859 (1965).

14. Katsoyannis, P.G., K. Fukuda, A. Tometski, K. Suzukr, and M. TILAK: The synthesis of the B-chain of insulin and its combination with natural or synthetic A-chain to generate insulin activity. J. Am. chem. Soc. 86, 930-932 (1964).

15. Katzen, H.M., and D. Stetren, Jr.: Hepatic glutathione-insulin transhydrogenase. Diabetes 11, 271280 (1962).

16. - F. Tretze, and D. Stertew, Jr.: Further studies on properties of hepatic glutathione-insulin transhydrogenase. J. biol. Chem. 238, 1006-1011 (1963).

17. Kanny, A.J.: Metabolism of peptide hormones. Brit. med. Bull., 16, 202-208 (1960).

18. KIMmeL, J.R., and H.G. PolLock: Studies of human insulin from nondiabetic and diabetic pancreas. Diabetes 16, 687-694 (1967).

19. Kotoulas, O.B., G.R. Morrison, and L. Recant: Glutathione-insulin transhydrogenase activity in pancreatic islets. Biochim. biophys. acta 97, 350-353 (1965).

20. LACY, P.E.: The pancreatic beta cell: Structure and function. New Engl. J. Med. 276, 187-195 (1967).

21. LeCompte, P.M.: "Insulitis" in early juvenile diabetes. Arch. Path. 66, 450-457 (1958).

22. LEVINE, R. : The action of insulin at the cell membrane. Amer. J. Med. 40, 691-694 (1966).

23. Manotn, A.M., G. Costanzi, and G.A. Zampa: Human insulin antibodies by immunofluorescent technique. Lancet 1964 I, 726.

24. Mfade, R.C., R.A. Stiglitz, and T.J. Kueist: The state of pancreatic and serum insulin: Results of immunoassay. Diabetes 14, 387-391 (1965).

25. Mejbaum, W.Z.: Über die Bestimmung kleiner pentosemengen insbesondere in derivaten der adenylsäure. Hoppe-Seylers $Z$. physiol. Chem. 258, 117-120 (1939).

26. Mrrsky, I. A.: The role of insulinase and insulinase inhibitors. Metabolism 5, 138-143 (1956).

27. - R. Jinks, and G. PerisutTr: The isolation and crystallization of human insulin. J. clin. Invest. 42, $1869-1872(1963)$.

28. Morgan, C.R., and A. Lazarow: Immunoassay of insulin: Two antibody system. Diabetes 12, 115-126 (1963).

29. O'Brien, D., D. ShapcotT, and C.C. Roy: Further studies on an abnormal insulin of diabetes mellitus. Diabetes 16, 572-575 (1967).

30. Power, L., C. LuCas, and J.W. ConN: A globulin system from human serum that augments the activity of crystalline insulin on the epididymal fat pad deficiency in diabetes mellitus. Metabolism 14, 104-109 (1965).

31. G.R. Rojas, and J.H. Londono: New evidence for I.L.A. cell origin of insulin-like activity in serum. Lancet 1967 I, 1123-1125.

32. Rafaelson, O.J., V. Lauris, and A.E. Renold: Localized intraperitoneal action of insulin on rat diaphragm and epididymal adipose tissue in vivo. Diabetes 14, 19-26 (1965). 
33. Rampensad, O.R., and I.G. Woov: Protein synthesis by ribosomes from heart muscle: Effect of insulin and diabetes. Science 149, 1102-1103 (1965).

34. Renold, A.E., A. Gonet, O.B. Crofrord, and D. VECchIo: Metabolic regulation in heterogenous systems: Some new questions about diabetes mellitus. Fed. Proc., 25, 827-831 (1966).

35. Roy, C.C., R.B. Elliotr, D.J. ShapcotT, and D. O'BRIEN: Resistance of insulinase: A genetic discriminant in diabetes mellitus. Lancet 1966 II, 1433 -. 1435 .

36. - R. Gotuin, D. Shapcott, and D. O'Brifin: Decreased incorporation of uracil-2-C $\mathrm{C}^{14}$ in the RNA fraction of mouse fibroblasts grown with pancreatic diabetic insulin. Program of the Society for Pediatric Research, April 1967 Meeting, P. 18.

37. Schwartz, I.L., and O. Hechter: Insulin structure and function. Reflections on the present state of the problem. Amer. J. Med. 40, 765-772 (1966).

38. ShapcotT, D.J.: Further studies on the abnormal insulin of diabetes mellitus. Thesis in partial fulfillment for M.S., Department of Pediatrics, University of Colorado, 1966.

39. Stobin, L.I., and F.H. Carpentere: Kinetic studies on the action of carboxypeptidase $A$ on bovine insulin and related model peptides. Biochemistry 5, 499$508(1966)$.

40. SMrrr, L.F.: Species variation in the amino acid sequence of insulin. Amer. J. Med. 40, 662-666 (1966).

41. Steiner, D.F., D. Conningham, L. Spigelman, and B. ATEN: Insulin biosynthesis: Evidence for a preeursor. Science 157, 697-700 (1967).
42. - , and P.E. OYer: The biosynthesis of insulin and a probable precursor of insulin by a human cell adenoma. Proc. nat. Acad. Sci. 57, 473-480 (1967).

43. Strmaler, L. : Disappearance of immunoreactive insulin in normal and adult-onset diabetic subjects. Diabetes 16, 652 - 655 (1967).

44. - , and R. B. EusrotT: Inheritance of a diabetic-serum factor inhibiting normal utilization of insulin. Lancet 1964 I, $956-957$.

45. Todaro, G.J., and H. Greme: Quantitative studies of the growth of mouse embryo cells in culture and their development into established lines. J. Cell Biol. 17, $299-313$ (1963).

46. TOMtzawa, H.H., and Y.D. HaLSEY: Isolation of an insulin degrading enzyme from beef liver. J. biol. Chem. 234, 307-310 (1959).

47. Vilimar-PaLASI, C., and J. LARNER: Insulin treatment and increased UDPG-glycogen transglucosylase activity in muscle. Arch. biochem. 94, 436-442 (1961).

48. Weber, G., and R.L. Singreat: Insulin: inducer of phosphofructokinase. The integrative action of insulin at the enzyme biosynthetic level. Life Sci. 4, $1993-$ 2002 (1965).

Claude C. Roy

Department of Pediatrics

University of Colorado

Medical Center

4200 East Ninth Avenue

Denver, Colorado USA 